\title{
EFFECT OF OCHRATOXIN A ON THE INTESTINAL MUCOSA AND MUCOSA-ASSOCIATED LYMPHOID TISSUES IN BROILER CHICKENS
}

\author{
Carmen SOlCAN ${ }^{1}$, Geta PAVEL ${ }^{1}$, Viorel Cezar Floristean ${ }^{1}$, \\ Ioan Sorin Beschea CHIRIAC ${ }^{1}$, Bogdan Gabriel ŞLENCU ${ }^{2}$ and Gheorghe SOLCAN ${ }^{1 *}$ \\ ${ }^{1}$ Faculty of Veterinary Medicine, University of Agricultural Science and Veterinary \\ Medicine 'Ion Ionescu de la Brad' Iasi, 8 M. Sadoveanu Alley, 700489, Iasi, Romania; \\ ${ }^{2}$ Faculty of Pharmacy, 'Grigore T. Popa' University of Medicine and Pharmacy Iasi, Iasi, \\ Romania
}

(Received 10 February 2014; accepted 29 October 2014)

The immunotoxic effect of ochratoxin A (OTA) on the intestinal mucosaassociated lymphoid tissue and its cytotoxic action on the intestinal epithelium were studied in broiler chickens experimentally treated with the toxin. From the 7 th day of life, 80 male broiler chickens (Ross 308 ) were randomly divided into four groups of 20 birds each. The three experimental groups (E1-3) were treated with OTA for 28 days (E1: $50 \mu \mathrm{g} / \mathrm{kg}$ body weight [bw]/day; E2: $20 \mu \mathrm{g} / \mathrm{kg}$ bw/day; E3: $1 \mu \mathrm{g} / \mathrm{kg} \mathrm{bw} /$ day) and the fourth group served as control. Histological examination of the intestinal mucosa and immunohistochemical staining for identification of CD4+, CD8+, TCR1 and TCR2 lymphocytes in the duodenum, jejunum and ileocaecal junction were performed, and CD4+/CD8+ and TCR1/TCR2 ratios were calculated. OTA toxicity resulted in decreased body weight gain, poorer feed conversion ratio, lower leukocyte and lymphocyte count, and altered intestinal mucosa architecture. After 14 days of exposure to OTA, immunohistochemistry showed a significant reduction of the lymphocyte population in the intestinal epithelium and the lamina propria. After 28 days of exposure, an increase in the CD4+ and CD8+ values in both the duodenum and jejunum of chickens in Groups E1 and E2 was observed, but the TCR1 and TCR2 lymphocyte counts showed a significant reduction. No significant changes were observed in Group E3. The results indicate that OTA induced a decrease in leukocyte and lymphocyte counts and was cytotoxic to the intestinal epithelium and the mucosa-associated lymphoid tissue, altering the intestinal barrier and increasing susceptibility to various associated diseases.

Key words: Ochratoxin A, broiler chickens, immunohistochemistry, intestinal mucosa-associated lymphoid tissue

Ochratoxin A (OTA) is a metabolite produced by some species of fungi belonging to genera Aspergillus and Penicillium, especially A. ochraceus and $P$.

\footnotetext{
*Corresponding author; E-mail: gsolcan@uaiasi.ro; Phone: 0040 (745) 302-684
} 
viridicatum (Elaroussi et al., 2006). OTA is strongly nephrotoxic (Stoev et al., 2010; Solcan et al., 2013), hepatotoxic, neurotoxic (Doi and Uetsuka, 2011), teratogenic and carcinogenic (Clark and Snedeker, 2006). According to the classification of the International Agency for Research on Cancer (1993), OTA belongs to Group 2B and has a strong immunosuppressive effect. A recent study of human blood mononuclear cells exposed to OTA showed increased levels of reactive oxygen species and 8-hydroxy-deoxyguanasine (8-OHdG), a marker of oxidative stress (Liu et al., 2012).

The first expression of OTA toxicity is immunosuppression, which may become clinically apparent before nephropathy is manifested, and it is associated with biochemical changes (Aleo et al., 1991).

OTA toxicity is accomplished through the action of free radicals, the products released by oxidative reactions and lipid peroxidation, which finally lead to cell death (Abdel-Wahhab et al., 2005). Free radicals play an important role in the alterations of cellular metabolic processes involving enzymes such as superoxide dismutase and catalase. OTA increases membrane lipid peroxidation (Omar et al., 1990). The polyunsaturated fatty acids of cell membranes and the cellular organelles are very sensitive to the free radical attack. Free radicals can initiate destructive chain reactions that affect lipid membranes, leading to the degradation of their normal structure and functionality (O'Brien and Dietrich, 2005). Alterations of the structural integrity of membranes can be associated with an increase of various lysosomal and peroxisomal enzymes in soluble cell fractions, followed by degenerative changes of the epithelium.

OTA inhibits protein synthesis by competing with phenylalanine in the aminoacylation of tRNA catalysed by phenylalanyl-tRNA synthetase. This process can affect the integrity of the cell organelle membranes and intercellular junction proteins (Sauvant et al., 2005).

The intestinal mucosa is the first barrier for various dietary toxins. OTA induces intestinal destructions as reported in both animals and in vitro intestinal models (Schrickx et al., 2006; Maresca and Fantini, 2010). After ingestion, OTA is partially absorbed by passive diffusion in unionised form through the stomach mucosa. OTA absorption mainly takes place in the proximal third of the jejunum. After absorption, OTA is diffused into various organs through the enterohepatic circulation, bound to serum albumins. Several mycotoxins (deoxynivalenol, OTA, aflatoxin B1) induce apoptosis of intestinal epithelial cells, enabling the uncontrolled penetration of undesirable substances and pathogens (Revajová et al., 2013). OTA directly or indirectly affects the host immune response and increases susceptibility to infections (Elaroussi et al., 2006).

The aim of this study was to investigate the influence of OTA exposure on white blood cell subsets, intestinal mucosa-associated lymphoid tissues and the structural changes of mucosae, in order to explain increased susceptibility to infections and decreased productivity. 
SOLCAN et al

\section{Materials and methods}

\section{Materials used}

All solvents, chemicals, solutions and reagents used in the study were of analytical grade (Sigma Chemicals Co.). Antibodies: primary mouse anti-chicken and unlabelled antibody: Southern Biotechnology Associates Antibody, primary; anti-CD4+ (clone CT-4), cat. no. 8210-09; TCR gd (clone TCR-1), cat. no. 8230-01; TCR VB1 (clone TCR-2), and CD8+ $\alpha$ (clone CT-8) were provided by Vector Laboratories, USA and diluted with Vectastain Elite. Specific kits for haematology (MS9 Vet) and an Olympus microscope CX 41 for immunohistochemical examinations were used. Ochratoxin A OEKANAL (purity 99.5\%, cat. no. 32937) was used.

\section{Ochratoxin A poisoning}

Eighty ( $\mathrm{n}=20$ /group) Ross 308 male broiler chickens (age: 7 days, body weight: $79.8 \pm 0.75 \mathrm{~g}$ ) obtained from the farm the Faculty were used in the experiment. All birds were reared on sawdust litter, maintained at standard conditions of temperature $\left(26 \pm 1{ }^{\circ} \mathrm{C}\right.$ during the first week of the experiment and $24 \pm$ $1{ }^{\circ} \mathrm{C}$ for the rest of the experimental period) and relative humidity, in a 12-hour light/dark cycle, and fed a balanced pellet diet and having access to drinking water ad libitum, in groups of 20 birds each. The birds of each group were kept in one pen. Analyses by ELISA (Fernandez et al., 1994) showed no detectable levels of mycotoxins ( $\mathrm{LOD}=2.5 \mathrm{ppb})$ in the pelleted diet, which had been delivered by the manufacturer as a diet free of mycotoxins.

The chickens were acclimatised to the keeping conditions for one week prior to the experiment and then the experimental groups were treated for a period of 28 days, as follows. Chickens of Group E1 received $50 \mu \mathrm{g}$ of OTA $/ \mathrm{kg}$ bw/day, by gavage, diluted in sterilised sunflower oil as eluent; pure crystalline OTA $(99.5 \%)$ was dissolved in chloroform $(1 \mathrm{mg} / 10 \mathrm{~mL})$ and then mixed with $90 \mathrm{ml}$ sterilised sunflower oil. Group E2 received $20 \mu \mathrm{g}$ OTA/kg bw/day; Group E3 received $1 \mu \mathrm{g}$ OTA/kg bw/day; the control group (C) received only eluent, in the same quantity as the experimental ones.

The body weight of the chickens was recorded at $\mathrm{T}_{0}$ and then on days 7 , 14, 21 and 28 of treatment, respectively. Feed consumption was recorded daily for each group (one measurement for the entire group) and the mean/chick was calculated weekly. The feed conversion ratio was calculated for each group at the end of the experiment as grams of feed/grams of body weight gain. Five chickens from each group were euthanised by an overdose of sodium thiopental on days 14, 21 and 28 day of treatment (on days 21, 28 and 35 of life, respectively). Prior to euthanasia, blood samples were withdrawn from the ulnar vein into a vacutainer containing K-EDTA for haematological examination. White blood cell 
counts (WBC) and the heterophil/lymphocyte $(\mathrm{H} / \mathrm{Lc})$ ratios were determined by an MS9 Vet (Melet Schloesing Lab, France) automated cell counter. Differential leukocyte count and the indirect thrombocyte count were determined in MayGrünwald-Giemsa stained blood smears using $\times 100$ magnification.

\section{Histological studies}

Samples of the proximal duodenum, jejunum and ileocaecal junction were collected from each euthanised chicken for macroscopic and histological examination. The samples were preserved in $10 \%$ buffered neutral formalin solution (pH 7.4), embedded in paraffin, cut into sections of $5 \mu \mathrm{m}$, then stained with haematoxylin-eosin and Gömöri trichrome stain. Four samples from each chicken were randomly evaluated (10 fields at a magnification of $\times 40$ ). Each section was used for measuring the height of the typical villi from the crypt mouth to the villus tip and the depth of the associated crypts from the crypt mouth to its base using an Olympus CX41 optical microscope (Hamburg, Germany). The ratios of villus height to crypt depth were calculated.

\section{Immunohistochemistry (IHC)}

Fixed gut samples were trimmed, embedded in paraffin and sectioned at $5 \mu \mathrm{m}$ thickness. The sections were de-waxed and epitopes were revealed by heating in $10 \mathrm{mmol}$ citric acid buffer (pH 6) for $10 \mathrm{~min}$ at $95^{\circ} \mathrm{C}$ in a microwave oven and then left at room temperature for $20 \mathrm{~min}$. Then the slides were washed twice in PBS (pH 7.5) for 5 min. Tissue sections were incubated with goat blocking serum, then with primary mouse anti-chicken antibodies and unlabelled $\mathrm{CD} 4+$, TCR gd (clone TCR-1), TCR VB1 (clone TCR-2) and CD8+ $\alpha$ (clone CT-8) antibodies (Southern Biotech), and then diluted 1:100 at room temperature in a humid chamber for $1 \mathrm{~h}$. After being washed with PBS, slides were incubated with the secondary antibody, HRP goat anti-mouse IgG, for $1 \mathrm{~h}$ in a humid chamber at $4{ }^{\circ} \mathrm{C}$, then washed with PBS and incubated with $\mathrm{ABC}$ Kit for $30 \mathrm{~min}$ in a humid chamber, then washed with PBS and incubated with DAB substrate for $5 \mathrm{~min}$ and counter-stained with Harris haematoxylin, clarified in xylene and mounted.

TCR1, TCR2, CD4+ and CD8+ T cells were counted using light microscopy (magnification: $\times 900$ ) in 10 randomly selected villi from the immunostained sections of the duodenum, jejunum and ileocaecal junction. The average number of cells per villus was calculated from a total of 50 villi (10 villi per chicken and 5 chickens per group). The ratios of CD4+/CD8+ T cells were also calculated.

\section{Statistical analysis}

The values were subjected to multivariate analysis of variance. Inter-group differences were assessed using Tukey 'post hoc' test (Szabó et al., 2014). The minimum level of significance was fixed at 0.001 . 
Table 1

Effect of OTA on chicken weight (mean \pm SD)

\begin{tabular}{lcccccc}
\hline Group & \multicolumn{4}{c}{ Chicken weight values during the experiment $(\mathrm{g})$} & $\begin{array}{c}\text { \% of weight gain } \\
\text { (g) between } \\
\text { days 0 and 28 }\end{array}$ \\
\cline { 2 - 6 } & $\mathrm{T}_{0}$ & $\mathrm{~T} 1$, day 7 $(\mathrm{n}=20)$ & $\mathrm{T} 2$, day 14 $(\mathrm{n}=20)$ & $\mathrm{T}$, day 21 $(\mathrm{n}=15)$ & T4, day 28 $(\mathrm{n}=10)$ & \\
\hline Control & $79.80 \pm 7.53^{\mathrm{a}}$ & $210.5 \pm 23.12^{\mathrm{b}}$ & $420.1 \pm 42.02^{\mathrm{b}}$ & $793.9 \pm 64.31^{\mathrm{b}}$ & $1653.1 \pm 134.20^{\mathrm{b}}$ & 100 \\
E1 & $79.50 \pm 6.65^{\mathrm{a}}$ & $121.5 \pm 15.19^{\mathrm{a}}$ & $265.1 \pm 46.32^{\mathrm{a}}$ & $421.3 \pm 57.21^{\mathrm{a}}$ & $891.2 \pm 98.65^{\mathrm{a}}$ & 53.90 \\
E2 & $79.10 \pm 8.91^{\mathrm{a}}$ & $160.6 \pm 13.21^{\mathrm{ab}}$ & $351.9 \pm 36.39^{\mathrm{ab}}$ & $673.7 \pm 75.87^{\mathrm{b}}$ & $1297.2 \pm 86.55^{\mathrm{b}}$ & 78.50 \\
E3 & $79.20 \pm 8.76^{\mathrm{a}}$ & $202.3 \pm 23.81^{\mathrm{b}}$ & $411.3 \pm 40.07^{\mathrm{b}}$ & $759.1 \pm 74.91^{\mathrm{b}}$ & $1550.8 \pm 105.14^{\mathrm{b}}$ & 93.82 \\
\hline
\end{tabular}

a,b significant difference between treatments at five different measurement times; means not sharing a superscript letter are significantly different

Feed consumption data and feed conversion ratio of the groups

\begin{tabular}{lccccc}
\hline \multirow{2}{*}{ Group } & \multicolumn{3}{c}{ Feed consumption data at different days of the experiment (grams) } & Feed conversion ratio \\
\cline { 2 - 4 } & Day 7 & Day 14 & Day 21 & Day 28 & (FCR) \\
\hline C & 205.3 & 393.8 & 690.3 & 1505.6 & 1.77 \\
E1 & 130.2 & 250.4 & 395.8 & 1010.6 & 2.20 \\
E2 & 164.7 & 342.2 & 570.4 & 1366.3 & 2.00 \\
E3 & 198.4 & 362.2 & 605.7 & 1461.2 & 1.78 \\
\hline
\end{tabular}

${ }^{*}$ at the end of the experiment, expressed in grams of feed/grams of body weight gain 
Table 3

Leukocyte counts in chickens during experimental ochratoxin A poisoning

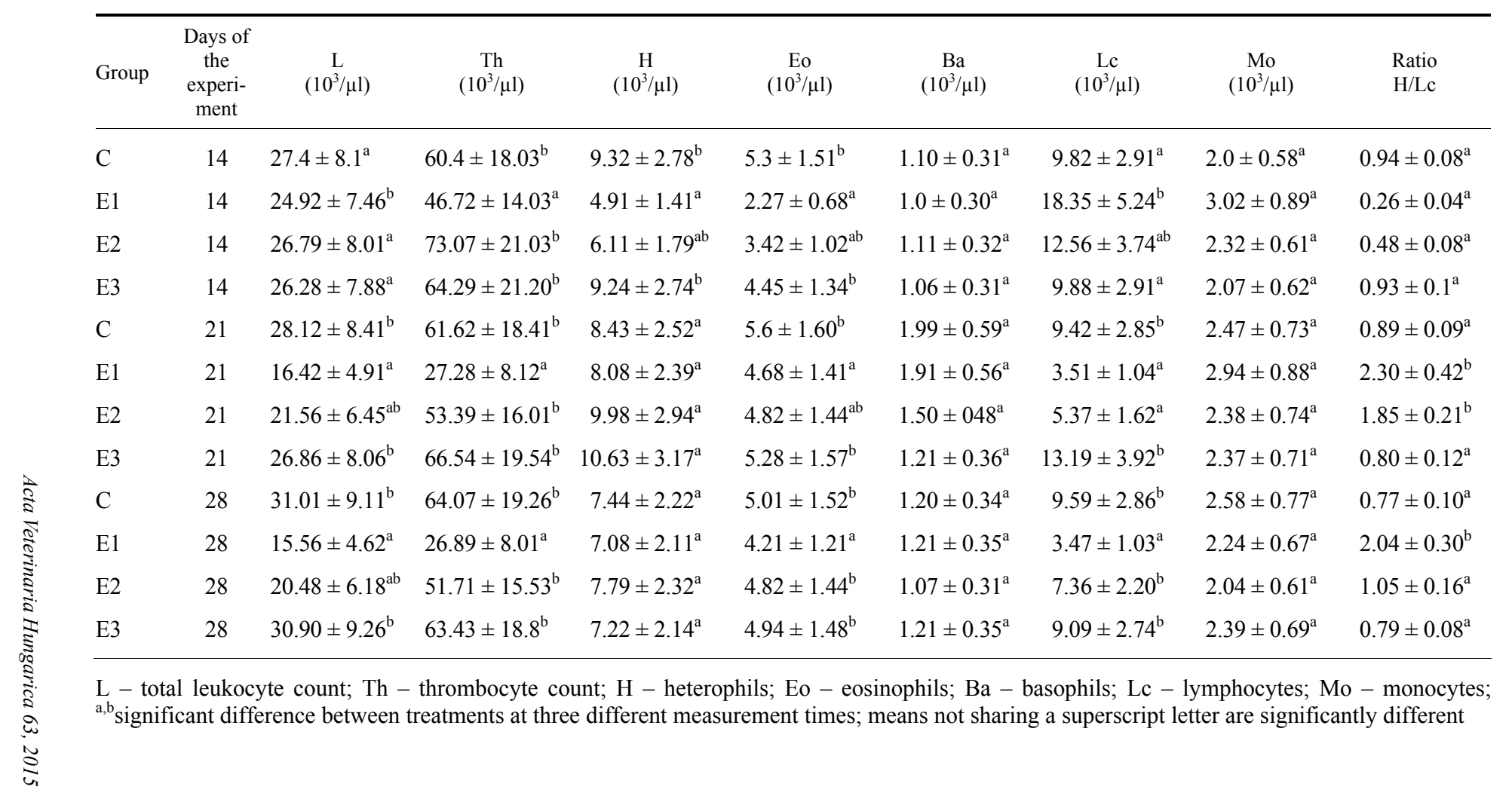


Table 4

Villus height and crypt depth of the intestinal mucosal epithelium $(\mu \mathrm{m})$

\begin{tabular}{|c|c|c|c|c|c|}
\hline & $\begin{array}{l}\text { Days of the } \\
\text { experiment }\end{array}$ & Control group & Group E1 & Group E2 & Group E3 \\
\hline \multicolumn{6}{|l|}{ Duodenum } \\
\hline Height $(\mathrm{H})$ & 14 & $1387.4 \pm 52.1^{\mathrm{b}}$ & $992.5 \pm 141.6^{\mathrm{a}}$ & $1110.7 \pm 124.1^{\mathrm{ab}}$ & $1349.9 \pm 134.4^{\mathrm{b}}$ \\
\hline Depth (D) & 14 & $212.4 \pm 44.9^{\mathrm{ab}}$ & $261.6 \pm 42.0^{\mathrm{b}}$ & $187.7 \pm 17.9^{\mathrm{a}}$ & $201.6 \pm 33.8^{\mathrm{ab}}$ \\
\hline $\mathrm{H} / \mathrm{D}$ & 14 & $6.53 \pm 2.03^{\mathrm{b}}$ & $3.79 \pm 0.98^{\mathrm{a}}$ & $5.82 \pm 0.97^{\mathrm{b}}$ & $6.71 \pm 0.97^{b}$ \\
\hline Height & 28 & $1481.9 \pm 114^{\mathrm{b}}$ & $1040.4 \pm 113^{\mathrm{a}}$ & $1219.8 \pm 132.7^{\mathrm{ab}}$ & $1425.8 \pm 169.5^{b}$ \\
\hline Depth & 28 & $197.7 \pm 31.3^{\mathrm{b}}$ & $228.7 \pm 22.9^{\mathrm{a}}$ & $209.7 \pm 31.6^{\mathrm{a}}$ & $182.0 \pm 29.5^{\mathrm{a}}$ \\
\hline $\mathrm{H} / \mathrm{D}$ & 28 & $7.50 \pm 1.09^{\mathrm{b}}$ & $4.55 \pm 1.12^{\mathrm{a}}$ & $5.35 \pm 1.02^{\mathrm{ab}}$ & $7.81 \pm 1.09^{b}$ \\
\hline \multicolumn{6}{|l|}{ Jejunum } \\
\hline Height & 14 & $1123.4 \pm 201.6^{\mathrm{b}}$ & $867.6 \pm 203.3^{\mathrm{a}}$ & $953.4 \pm 184.8^{\mathrm{ab}}$ & $1121.3 \pm 198.1^{\mathrm{b}}$ \\
\hline Depth & 14 & $164.6 \pm 32.6^{\mathrm{a}}$ & $176.9 \pm 48.9^{\mathrm{b}}$ & $170.8 \pm 42.3^{\mathrm{b}}$ & $163.9 \pm 21.8^{\mathrm{a}}$ \\
\hline $\mathrm{H} / \mathrm{D}$ & 14 & $6.84 \pm 1.03^{\mathrm{b}}$ & $4.92 \pm 1.2^{\mathrm{a}}$ & $5.60 \pm 1.01^{\mathrm{a}}$ & $6.87 \pm 1.21^{\mathrm{b}}$ \\
\hline Height & 28 & $1241.7 \pm 202.3^{\mathrm{b}}$ & $967.2 \pm 205.9^{\mathrm{a}}$ & $1183.2 \pm 199.6^{\mathrm{ab}}$ & $1238.1 \pm 204.1^{\mathrm{b}}$ \\
\hline Depth & 28 & $185.9 \pm 46^{\mathrm{a}}$ & $219.9 \pm 51.0^{\mathrm{b}}$ & $206.4 \pm 43.2^{\mathrm{a}}$ & $183.7 \pm 26.1^{\mathrm{a}}$ \\
\hline $\mathrm{H} / \mathrm{D}$ & 28 & $6.70 \pm 1.02^{\mathrm{b}}$ & $4.41 \pm 0.98^{\mathrm{a}}$ & $5.74 \pm 1.02^{\mathrm{ab}}$ & $6.76 \pm 1.10^{\mathrm{b}}$ \\
\hline \multicolumn{6}{|c|}{ Ileocaecal junction } \\
\hline Height & 14 & $661.7 \pm 106.1^{\mathrm{b}}$ & $543.5 \pm 131.8^{\mathrm{a}}$ & $561.5 \pm 84^{\mathrm{a}}$ & $659.3 \pm 101.2^{\mathrm{b}}$ \\
\hline Depth & 14 & $114.7 \pm 29.1^{\mathrm{a}}$ & $121.3 \pm 20.9^{\mathrm{a}}$ & $112.9 \pm 17.2^{\mathrm{a}}$ & $112.3 \pm 21.2^{\mathrm{a}}$ \\
\hline $\mathrm{H} / \mathrm{D}$ & 14 & $5.79 \pm 1.01^{\mathrm{b}}$ & $4.48 \pm 0.54^{\mathrm{a}}$ & $5.01 \pm 0.1^{\mathrm{ab}}$ & $5.77 \pm 0.98^{b}$ \\
\hline Height & 28 & $780.2 \pm 109.3^{\mathrm{b}}$ & $609.3 \pm 129.1^{\mathrm{a}}$ & $701.2 \pm 216.3^{\mathrm{ab}}$ & $785.1 \pm 103.2^{\mathrm{b}}$ \\
\hline Depth & 28 & $139.7 \pm 29.9^{\mathrm{a}}$ & $149.9 \pm 43.9^{\mathrm{b}}$ & $146.8 \pm 56^{\mathrm{a}}$ & $135.8 \pm 20.8^{\mathrm{a}}$ \\
\hline $\mathrm{H} / \mathrm{D}$ & 28 & $5.61 \pm 1.1^{\mathrm{b}}$ & $4.08 \pm 0.51^{\mathrm{a}}$ & $4.80 \pm 0.41^{\mathrm{a}}$ & $5.67 \pm 1.02^{b}$ \\
\hline
\end{tabular}

a,b significant difference between treatments at two different measurement times; means not sharing a superscript letter are significantly different 


\section{Table 5}

TCR1/TCR2 and CD4+/CD8+ intraepithelial lymphocyte ratios during the experiment

\begin{tabular}{|c|c|c|c|c|c|c|c|c|}
\hline \multirow{2}{*}{$\begin{array}{l}\text { Days of } \\
\text { the ex- } \\
\text { peri- } \\
\text { ment }\end{array}$} & \multicolumn{4}{|c|}{ TCR1/TCR2 ratio } & \multicolumn{4}{|c|}{$\mathrm{CD} 4+/ \mathrm{CD} 8+$ ratio } \\
\hline & Control group & Group E1 & Group E2 & Group E3 & Control group & Group E1 & Group E2 & Group E3 \\
\hline \multicolumn{9}{|c|}{ Duodenum } \\
\hline 14 & $0.32 \pm 0.12^{\mathrm{a}}$ & $0.53 \pm 0.23^{\mathrm{b}}$ & $0.52 \pm 0.16^{\mathrm{b}}$ & $0.33 \pm 0.07^{\mathrm{a}}$ & $0.64 \pm 0.18^{\mathrm{a}}$ & $0.70 \pm 0.22^{\mathrm{a}}$ & $0.82 \pm 0.27^{\mathrm{a}}$ & $0.67 \pm 0.21^{\mathrm{a}}$ \\
\hline 21 & $0.52 \pm 0.18^{\mathrm{a}}$ & $0.55 \pm 0.27^{\mathrm{a}}$ & $0.60 \pm 0.21^{\mathrm{a}}$ & $0.55 \pm 0.19^{\mathrm{a}}$ & $1.33 \pm 0.32^{\mathrm{b}}$ & $0.90 \pm 0.33^{\mathrm{a}}$ & $1.13 \pm 0.32^{\mathrm{b}}$ & $1.22 \pm 0.29^{b}$ \\
\hline 28 & $1.23 \pm 0.32^{\mathrm{b}}$ & $0.92 \pm 0.34^{\mathrm{a}}$ & $1.05 \pm 0.37^{\mathrm{b}}$ & $1.21 \pm 0.24^{\mathrm{b}}$ & $1.09 \pm 0.25^{\mathrm{a}}$ & $1.88 \pm 0.53^{\mathrm{b}}$ & $1.41 \pm 0.48^{\mathrm{ab}}$ & $1.12 \pm 0.32^{\mathrm{a}}$ \\
\hline \multicolumn{9}{|c|}{ Jejunum } \\
\hline 14 & $0.35 \pm 0.07^{\mathrm{a}}$ & $0.33 \pm 0.13^{\mathrm{a}}$ & $0.32 \pm 0.12^{\mathrm{a}}$ & $0.33 \pm 0.06^{\mathrm{a}}$ & $0.88 \pm 0.24^{\mathrm{a}}$ & $0.75 \pm 0.27^{\mathrm{a}}$ & $0.80 \pm 0.21^{\mathrm{a}}$ & $0.88 \pm 0.19^{\mathrm{a}}$ \\
\hline 21 & $0.45 \pm 0.10^{\mathrm{a}}$ & $0.38 \pm 0.17^{\mathrm{a}}$ & $0.41 \pm 0.18^{\mathrm{a}}$ & $0.50 \pm 0.16^{\mathrm{a}}$ & $0.75 \pm 0.18^{\mathrm{b}}$ & $0.12 \pm 0.04^{\mathrm{a}}$ & $0.33 \pm 0.11^{\mathrm{ab}}$ & $0.75 \pm 0.21^{\mathrm{b}}$ \\
\hline 28 & $1.23 \pm 0.26^{\mathrm{a}}$ & $1.52 \pm 0.41^{\mathrm{b}}$ & $1.30 \pm 0.44^{\mathrm{a}}$ & $1.37 \pm 0.32^{\mathrm{a}}$ & $0.74 \pm 0.22^{\mathrm{b}}$ & $0.13 \pm 0.05^{\mathrm{a}}$ & $0.37 \pm 0.19^{\mathrm{ab}}$ & $0.76 \pm 0.24^{\mathrm{b}}$ \\
\hline \multicolumn{9}{|c|}{ Ileocaecal junction } \\
\hline 14 & $0.41 \pm 0.14^{\mathrm{b}}$ & $0.11 \pm 0.04^{\mathrm{a}}$ & $0.16 \pm 0.07^{\mathrm{a}}$ & $0.41 \pm 0.12^{\mathrm{b}}$ & $1.12 \pm 0.17^{\mathrm{a}}$ & $1.36 \pm 0.35^{\mathrm{a}}$ & $1.28 \pm 0.30^{\mathrm{a}}$ & $1.13 \pm 0.31^{\mathrm{a}}$ \\
\hline 21 & $1.02 \pm 0.26^{\mathrm{a}}$ & $2.61 \pm 0.52^{\mathrm{b}}$ & $1.55 \pm 0.61^{\mathrm{ab}}$ & $1.07 \pm 0.27^{\mathrm{a}}$ & $1.02 \pm 0.29^{\mathrm{a}}$ & $2.77 \pm 0.82^{\mathrm{b}}$ & $1.56 \pm 0.27^{\mathrm{ab}}$ & $1.05 \pm 0.24^{\mathrm{a}}$ \\
\hline 28 & $1.34 \pm 0.32^{\mathrm{a}}$ & $1.71 \pm 0.48^{\mathrm{b}}$ & $1.56 \pm 0.57^{\mathrm{a}}$ & $1.33 \pm 0.43^{\mathrm{a}}$ & $0.62 \pm 0.21^{\mathrm{a}}$ & $1.28 \pm 0.43^{\mathrm{b}}$ & $0.72 \pm 0.21^{\mathrm{a}}$ & $0.65 \pm 0.16^{\mathrm{a}}$ \\
\hline
\end{tabular}




\section{Animal ethics approval}

The study was approved by the Council of Ethics of the University of Agricultural Sciences and Veterinary Medicine of Iasi, Romania (approval number: 638/20.07.2012).

\section{Results}

\section{Variation in chicken weight}

The weights of chickens in Group E1 were highly significantly smaller than those of the control chickens. The body weight values of chickens in Group E2 were situated between those of the chickens in Groups E1 and E3, whereas the weights of chickens in Group E3 were not significantly different from those of the control birds (Table 1). Feed conversion was clearly poorer in Groups E1 and E2 (Table 2).

\section{Haematological analysis}

A significant decrease in thrombocyte and total leukocyte counts was observed in chickens of Group E1 after day 14 and in Group E2 after day 21 of the experiment, compared with the control chickens. This decrease continued with the chickens' advancing age and days of treatment (a significant decrease was noted in Group E1 after days 21 and 28 of the experiment). There was also a significant decrease of the H/Lc ratio in Groups E1 and E2 on day 14, followed by a considerable increase on days 21 and 28, as compared to the control group. Group E3 was the only experimental group in which there were no significant changes in total and differential leukocyte and thrombocyte counts (Table 3).

At days 14 and 28 of the experiment the chickens of Group E1 showed a significant decrease in the height of the duodenal villi. Villus height/crypt depth ratio in the duodenum decreased with the increase in exposure length and OTA dose, except in the control group and Group E3. Similar changes were found in the jejunum and at the ileocaecal junction (Table 4).

The intestinal mucosa of control chickens was physiological throughout the experiment (Fig. 1a). OTA cytotoxicity was observed after one week of exposure in Groups E1 and E2 and after 4 weeks of exposure in Group E3. The simple prismatic epithelium with brush border was modified, depending on the OTA dose and the exposure time. Epithelial cells were higher, sometimes without brush border, with big and multiple nuclei rich in dispersed chromatin.

Areas of necrosis were present in the intestine of chickens of Group E1. In the altered zones the epithelium seemed to be detached from the basal membrane, and showed a spongy structure due to the numerous small vacuoles that occurred mainly in the epithelial cells. Lymphocytes were observed in the epithelial layer and also in the lamina propria (Fig. 1b). The lamina propria contained fibroblasts, connective fibres, blood capillaries and large vacuoles. 


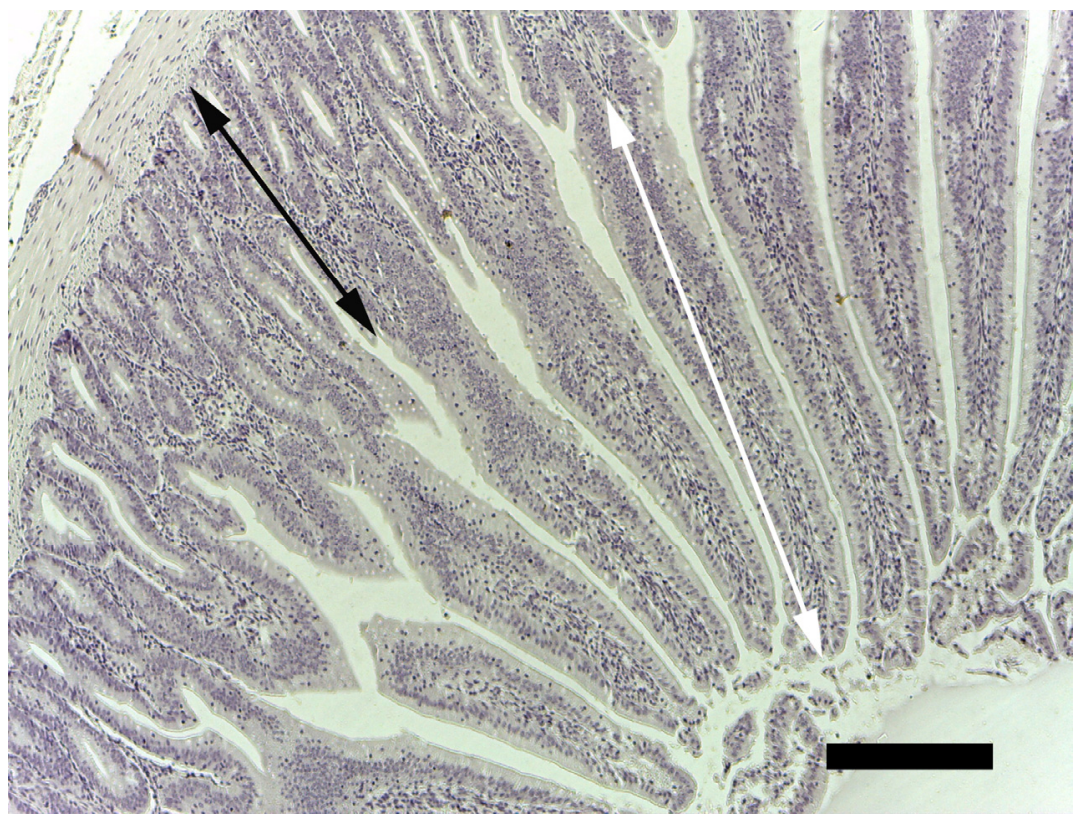

Fig. 1a. Duodenum of a control chicken on day 28. Normal structure, height of villi (white arrow) and depth of glands (black arrow). Gömöri trichrome stain. Bar $=200 \mu \mathrm{m}$

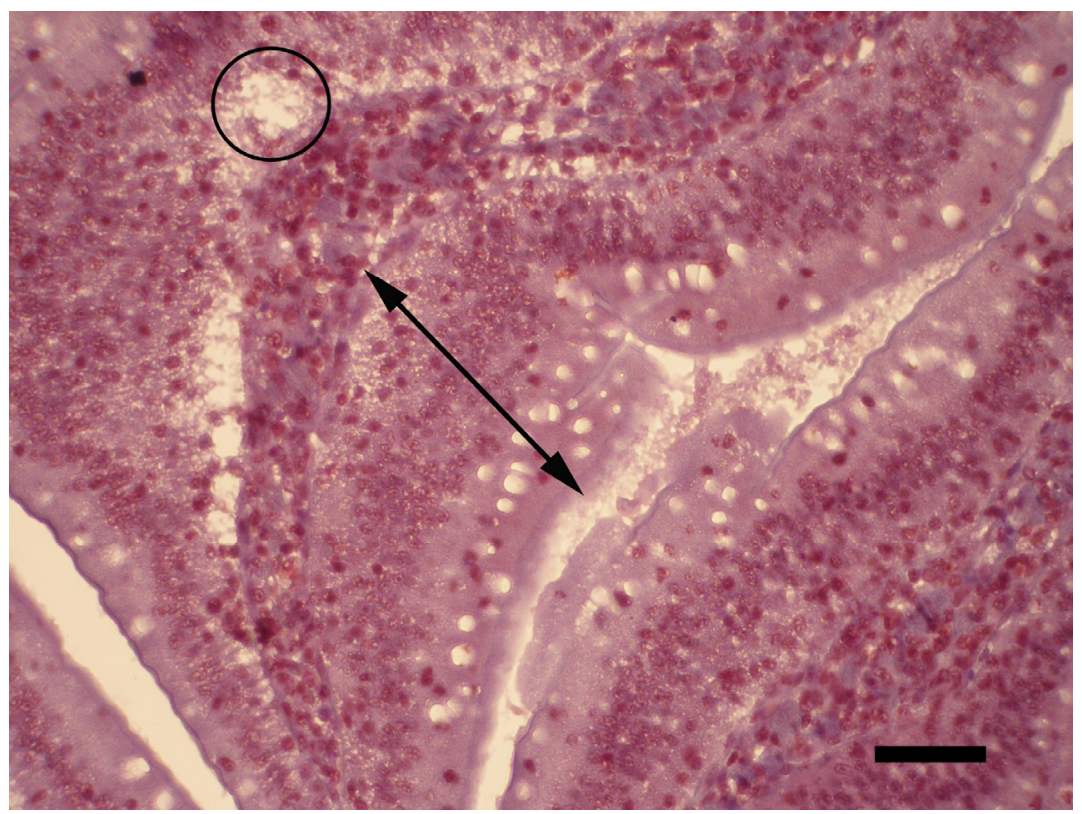

Fig. 1b. Duodenum of a chicken exposed to OTA for 28 days (E1). CD4+ lymphocytes. Mucosal epithelium with giant cells, without brush border (black arrow) and numerous small vacuoles (circle). Immunohistochemical (IHC) staining for LT CD4+. Bar $=200 \mu \mathrm{m}$ 
SOLCAN et al

The intestinal villi of the jejunum in Groups E1 (Fig. 2a) and E2 had a larger diameter than those in the control group and Group E3 (Fig. 2b). The glands of the lamina propria in the jejunum and at the ileocaecal junction were altered, showing numerous cell divisions and the presence of intraepithelial and periglandular lymphocytes (Figs $3 \mathrm{a}$ and $3 \mathrm{~b}$ ). Modified villi alternated with some apparently normal ones.

Altered villi became obvious after 14 days of exposure and their number progressively increased with the OTA dose and the duration of exposure to OTA in Groups E1 and E2.

A significant decrease in the numbers of TCR1, TCR2, CD4+ and CD8+ intraepithelial lymphocytes as a consequence of exposure to OTA was observed in the duodenum and jejunum as well as at the ileocaecal junction (Tables 5 and 6 ).

Histological examination demonstrated high numbers of CD4+ and CD8+ lymphocytes in the lamina propria, especially after 28 days of exposure to OTA in chickens of Groups E1 and E2. Intraepithelial lymphocytes of the lamina propria showed nuclear signs of cell death such as pyknosis and cortical hyperchromatosis.

\section{Discussion}

OTA administration caused a marked decrease in body weight and an increase in the feed conversion ratio in chickens from Groups E1 and E2. The results of this study are in accordance with the findings of another research, in which the feed intake of broilers fed diets contaminated with 0.4 and $0.8 \mathrm{mg}$ OTA $/ \mathrm{kg}$ of feed was lower than that of the control, whereas the feed conversion ratio was 10-20 per cent higher than in the control group (Elaroussi et al., 2006, cited by Battacone et al., 2010).

The age-related haematological profile observed in the control group of chickens in this study has been reported by Wakenell (2010).

OTA in the diet caused dose- and time-dependent changes in the leukogram and in thrombocyte counts. A myelosuppressive effect was demonstrated after 14 days of exposure in chickens treated with the highest dose of OTA (Group E1), concomitantly with an increase in the specific immune response (increase of lymphocyte counts). The pattern of the leukogram with a high H/Lc ratio on days 21 and 28 in the same groups demonstrated the immunosuppressive effect of OTA, suggesting that OTA is a chronic immunosuppressive agent. Such a property of mycotoxins has also been reported by Janaczyk et al. (2006) and Shlig (2009) in their studies on ochratoxin and aflatoxin, respectively. The H/Lc ratio quantifies the balance between the nonspecific, fast-acting defence provided by heterophils and the antigen-specific, slower-acting defence by lymphocytes and is regarded as a general biomarker relevant to immune function in poultry (Talebi et al., 2005). 


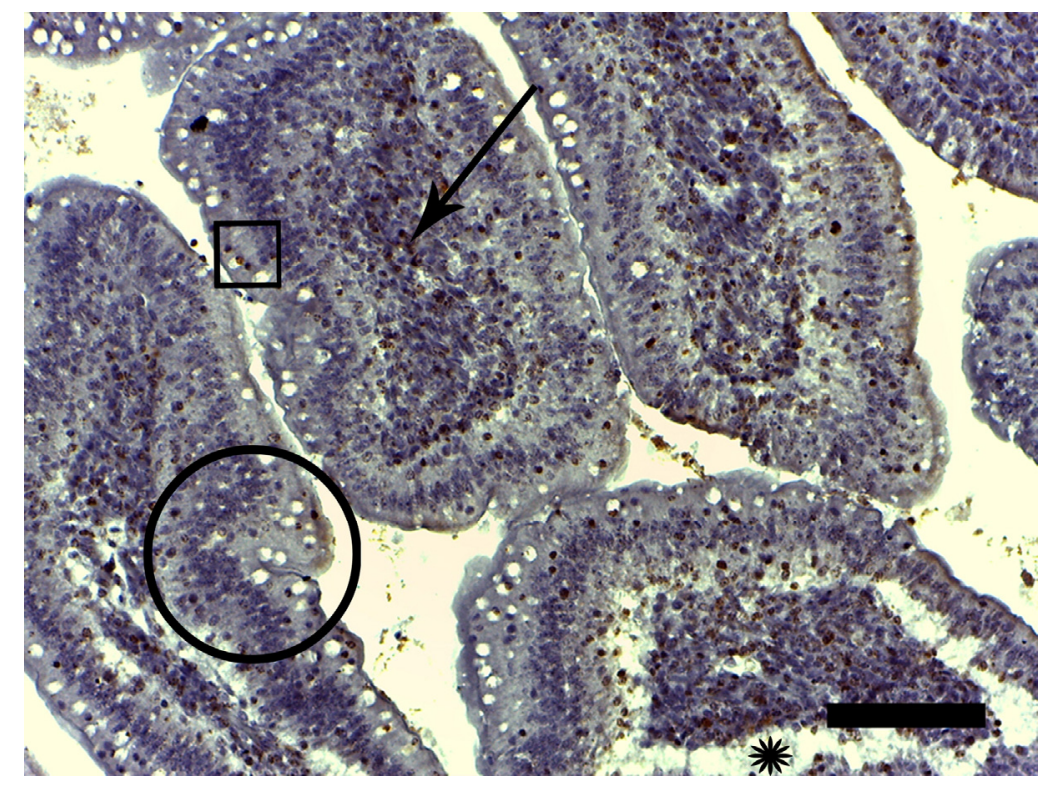

Fig. 2a. Jejunal villi of a chicken exposed to OTA for 21 days (E1). Mucosal epithelium with giant cells (black circle), without brush border and numerous small vacuoles (black star). Epithelium detached from the basal membrane; lymphocytes in the lamina propria (black arrow) and in intraepithelial location (black square). IHC staining for LT CD8+. Bar $=50 \mu \mathrm{m}$

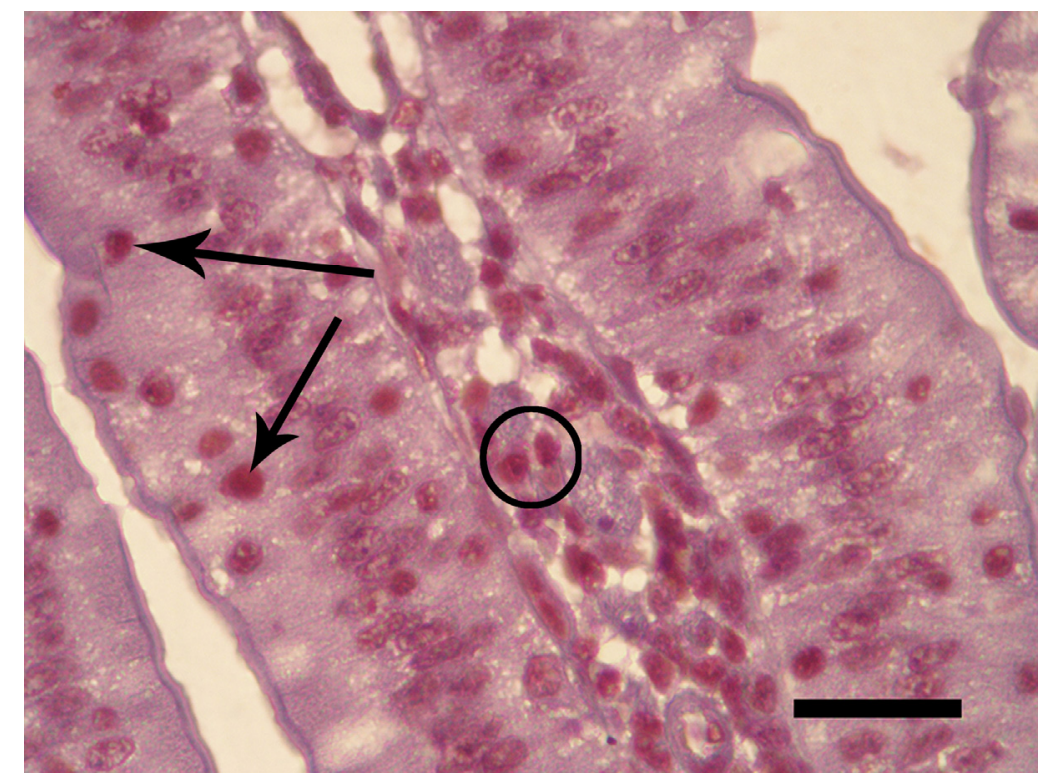

Fig. 2b. Jejunal villi of a chicken exposed to OTA for 21 days (E3). Mucosal epithelium without brush border. CD8+ lymphocytes in intraepithelial location (black arrows) and in the lamina propria (black circle). IHC staining for LT CD $8+$. Bar $=100 \mu \mathrm{m}$ 


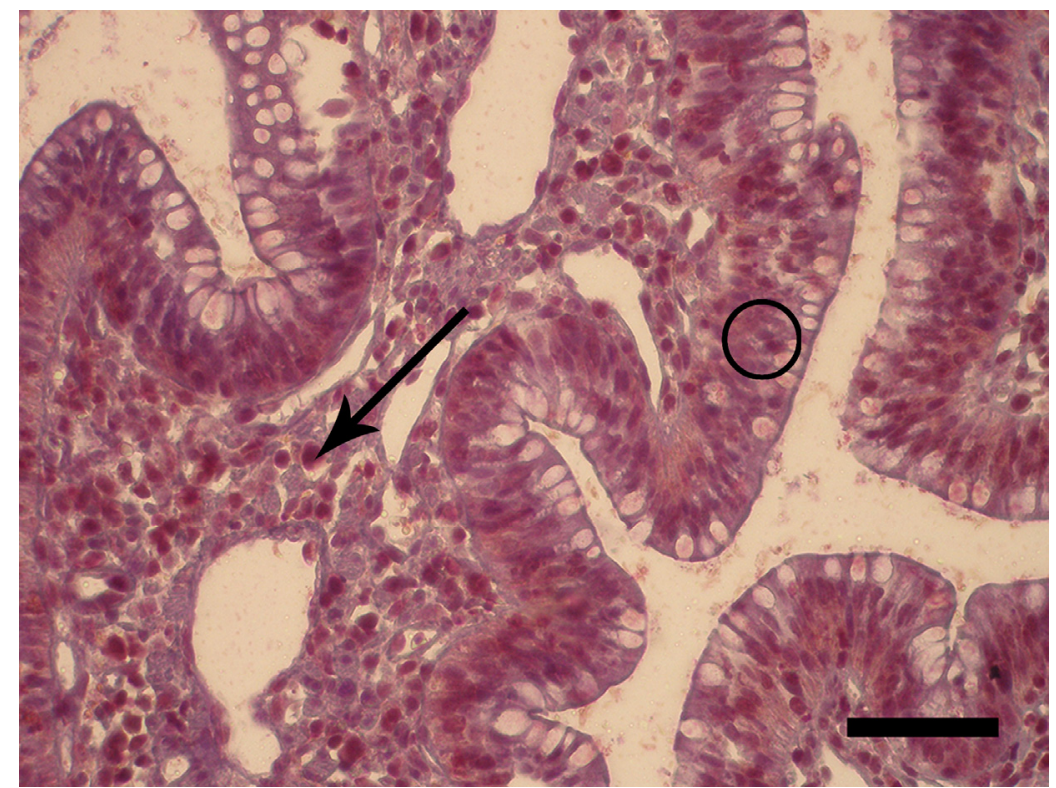

Fig. 3a. Villi of the ileocaecal junction of a chicken exposed to OTA for 28 days (E2). TCR1 lymphocytes in intraepithelial location (black circle) and in the lamina propria (black arrow). IHC staining for LT TCR1. Bar $=100 \mu \mathrm{m}$

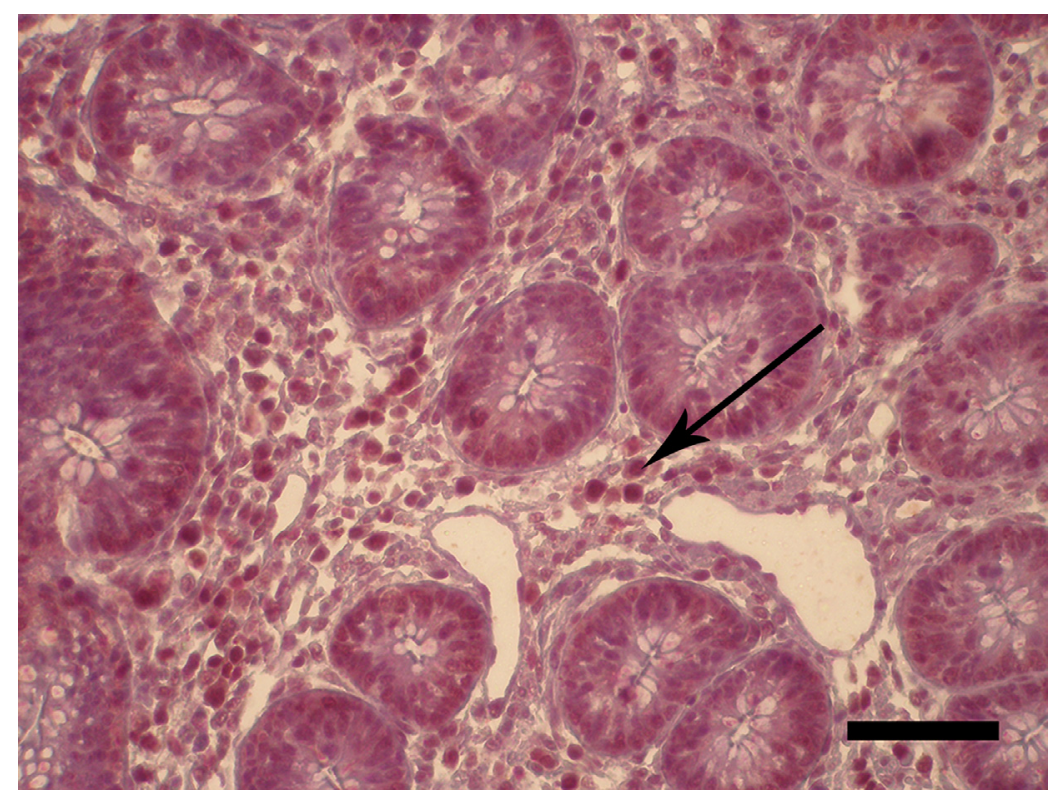

Fig. 3b. Lamina propria of the mucosa at the ileocaecal junction in a chicken exposed to OTA for 28 days (E2). TCR2 intraepithelial lymphocytes of the lamina propria (black arrow). IHC staining for TCR2. Bar $=100 \mu \mathrm{m}$ 
The intestinal mucosa represents the first barrier to various dietary toxins. OTA induces intestinal destruction reported in both animals and in vitro intestinal models (Schrickx et al., 2006; Maresca and Fantini, 2010). In vivo it causes intestinal epithelial cell apoptosis, enabling the uncontrolled penetration of undesirable substances and pathogens (Revajová et al., 2013), and thus predisposing to intestinal infections. OTA had harmful effects on chickens even in concentrations as low as $0.05-2 \mathrm{ppm}$. Intestinal inflammation, diarrhoea and increased bacterial translocation occurred after OTA exposure. These effects are followed by impaired epithelial barrier function resulting in changes in the intestinal mucosa (Ranaldi et al., 2009).

In this experiment, the cytotoxicity of OTA was expressed in modifications of villus architecture, consisting of shortened villi, hyperplastic crypts and the appearance of prismatic epithelium with altered brush border. Architectural changes of the mucosal lesions are initiated by an increase in the number of intraepithelial lymphocytes. Crypt hyperplasia and elongation is a process that precedes the compensatory shortening of villi (Oswald et al., 2003). Crypt elongation may be caused by the interaction of stromal cells with the epithelium, by the secretion of various cytokines and the growth factors released by inflammatory cells. In advanced stages of the process, matrix metalloproteinase and tissue inhibitors may play an important role in the development of changes in mucosal architecture (Vandenbroucke et al., 2011). Crypt hyperplasia is the next architectural change in the evolution of mucosal lesions initiated by the increased number of intraepithelial lymphocytes (Grenier and Applegate, 2013). The local immune system is also damaged by mycotoxins, resulting in increased susceptibility to infections. Previous studies have shown that OTA induced degenerative and necrotic changes and desquamation of the epithelium in the duodenal and jejunal mucosa, increasing the susceptibility to coccidiosis (Stoev et al., 2002; Koynarski et al., 2007). OTA also increased the susceptibility to, and aggravated the clinicopathological picture of, salmonellosis (Elissalde et al., 1994; Fukata et al., 1995; Gupta et al., 2005; Gupta et al., 2008) and colibacillosis (Kumar et al., 2003; Kumar et al., 2004). Either directly or indirectly, OTA affects the host's immune response and increases susceptibility to infections (Elaroussi et al., 2006).

At higher levels of aflatoxin exposure (1 mg aflatoxin B1/kg of diet), Kumar and Balachandran (2009) observed catarrhal enteritis with lymphocytic or mononuclear cell infiltrations in the intestine of broilers fed the toxin contaminated ration for 4 weeks. Awad et al. (2013) observed that the feeding of broilers with wheat naturally contaminated with deoxynivalenol (5 $\mathrm{mg}$ of DON$/ \mathrm{kg}$ ) for 21 days decreased the absolute and relative weights of the small intestine and caused histological alterations (shortening and thinning) of the intestinal villi, especially in the duodenum. Fairchild et al. (2005) found that the feeding of both fusaric acid and diacetoxyscripenol to turkey poults for 18 days decreased enterocyte height at mid-villus by $59 \%$, strongly indicating that these mycotoxins 
are capable of altering digestive and absorptive functions. On the other hand, Sklan et al. (2003) reported that the feeding of T-2 toxin or diacetoxyscripenol to poults at levels up to $1 \mathrm{ppm}$ for 32 days did not depress but enhanced growth and did not influence antibody production but caused changes in small intestinal morphology, especially in the jejunum where the villi became shorter and thinner. These changes appear as an indirect response to dietary trichothecenes.

T-lymphocyte subpopulations in the intestine depend on the age, the genetic heritage and the intestinal region. These cell populations indicate the cellular maturity of the mucosa-associated lymphoid tissue (Lillehoj and Chung, 1992). The number of these cells in birds could provide information about susceptibility or resistance to infectious diseases. The numbers of TCR1, TCR2, CD4+ and CD8+ intraepithelial lymphocytes generally decreased in chickens of Groups E1 and E2, but the decrease in the numbers of CD4+ and CD8+ was not significant throughout the experiment. IHC staining for CD4+ seems to be the best method for assessing the number and distribution of intraepithelial lymphocytes in normal villi. Intraepithelial lymphocytes are active components of the mucosal immune system, the number of which increases under the influence of various antigens from the intestinal lumen (microorganisms or toxic agents). Large numbers of CD4+ lymphocytes were observed in the duodenum and at the ileocaecal junction because of local stimulation by various antigens and in relation to age and associated antigenic aggressions (Hudacko et al., 2013). Cholera toxin primarily acts through augmenting CD4 $+\mathrm{T}$ cell priming, leading to a strong induction of antigen-specific $\mathrm{T}$ cells of both the $\mathrm{T}$ helper Th1 and Th2 subtypes (Hörnquist et al., 1996).

CD4+ and CD8+ lymphocytes from the intestinal villi act as effector cells initiating immediate mucosal immune response to various antigens (Shi et al., 1999). Oral administration of protein antigen is thought to induce suppressive $T$ cells that most often have been found to express CD8 (Hörnquist et al., 1996). In the present experiment, similar lesions were observed in the jejunum after 21 days of exposure to OTA. The increase in CD8+ lymphocytes might be linked with susceptibility to intestinal infections associated with malabsorption (Kunisawa et al., 2007).

The immune response is severely affected in the absence of CD4+ cells (Hörnquist et al., 1996). CD4+ cells have an important role in the generation and maintenance of cytotoxic CD8+ and memory cells (Yo-Ping et al., 2011). The $\mathrm{CD} 4+/ \mathrm{CD} 8+$ balance influences the immune response and the pathogenesis of some diseases. CD8+ T cells may exert local mucosal down-regulation of the intestinal immune responses (Hörnquist et al., 1996).

The increased number of CD4+ intraepithelial lymphocytes, the epithelial destructions and the high number of lymphocytes in the lamina propria observed in this experiment in the duodenum and at the ileocaecal junction of Group E1 chickens after 28 days of exposure to OTA were signs of intestinal inflammation. 
Table 6

Mucosal reactivity reflected by the variation of TCR1, TCR2, CD4+ and CD8+ lymphocytes in the control and experimental groups

\begin{tabular}{|c|c|c|c|c|c|}
\hline & \multirow{2}{*}{$\begin{array}{l}\text { Marker } \\
\text { type }\end{array}$} & \multirow{2}{*}{ Group } & \multicolumn{3}{|c|}{ Day of exposure to ochratoxin A } \\
\hline & & & 14 & 21 & 28 \\
\hline \multirow{16}{*}{ Duodenum } & \multirow{4}{*}{ CD4 } & $\mathrm{C}$ & $21.2 \pm 1.2^{\mathrm{a}}$ & $22.8 \pm 3.1^{\mathrm{b}}$ & $20.9 \pm 2.1^{\mathrm{a}}$ \\
\hline & & E1 & $20.5 \pm 1.8^{\mathrm{a}}$ & $10.2 \pm 1.1^{\mathrm{a}}$ & $27.2 \pm 1.3^{\mathrm{b}}$ \\
\hline & & E2 & $20.7 \pm 1.8^{\mathrm{a}}$ & $16.1 \pm 1.9^{\mathrm{ab}}$ & $23.4 \pm 1.7^{\mathrm{ab}}$ \\
\hline & & E3 & $22.3 \pm 1.12^{\mathrm{a}}$ & $23.1 \pm 1.02^{b}$ & $21.1 \pm 1.8^{\mathrm{a}}$ \\
\hline & \multirow{4}{*}{ TCR1 } & $\mathrm{C}$ & $12.2 \pm 1.2^{\mathrm{a}}$ & $11.6 \pm 1.1^{\mathrm{a}}$ & $10.4 \pm 1.9^{\mathrm{a}}$ \\
\hline & & E1 & $10.9 \pm 2.1^{\mathrm{b}}$ & $11.1 \pm 1.8^{\mathrm{a}}$ & $9.1 \pm 2.1^{\mathrm{a}}$ \\
\hline & & E2 & $11.7 \pm 1.3^{\mathrm{a}}$ & $10.9 \pm 1.6^{\mathrm{a}}$ & $9.7 \pm 1.5^{\mathrm{a}}$ \\
\hline & & E3 & $12.01 \pm 1.2^{\mathrm{a}}$ & $11.2 \pm 1.3^{\mathrm{a}}$ & $10.1 \pm 1.3^{\mathrm{a}}$ \\
\hline & \multirow{4}{*}{ TCR2 } & $\mathrm{C}$ & $37.1 \pm 1.2^{\mathrm{b}}$ & $22.1 \pm 2.2^{\mathrm{a}}$ & $8.4 \pm 1.3^{\mathrm{a}}$ \\
\hline & & E1 & $15.7 \pm 1.3^{\mathrm{a}}$ & $20.1 \pm 1.9^{\mathrm{a}}$ & $9.8 \pm 1.4^{\mathrm{a}}$ \\
\hline & & E2 & $22.2 \pm 1.6^{\mathrm{ab}}$ & $18.1 \pm 1.1^{\mathrm{a}}$ & $9.2 \pm 1.2^{\mathrm{a}}$ \\
\hline & & E3 & $36.1 \pm 2.1^{\mathrm{b}}$ & $20.5 \pm 1.1^{\mathrm{a}}$ & $8.3 \pm 1.3^{\mathrm{a}}$ \\
\hline & \multirow{4}{*}{ CD8 } & $\mathrm{C}$ & $32.8 \pm 1.3^{b}$ & $17.1 \pm 1.4^{\mathrm{b}}$ & $19.1 \pm 1.4^{b}$ \\
\hline & & E1 & $29.1 \pm 1.2^{\mathrm{a}}$ & $11.3 \pm 1.1^{\mathrm{a}}$ & $14.4 \pm 2.1^{\mathrm{a}}$ \\
\hline & & E2 & $25.2 \pm 1.3^{\mathrm{a}}$ & $14.2 \pm 1.1^{\mathrm{ab}}$ & $16.5 \pm 1.4^{\mathrm{ab}}$ \\
\hline & & E3 & $33.1 \pm 1.5^{\mathrm{b}}$ & $18.9 \pm 1^{\mathrm{b}}$ & $18.7 \pm 1.3^{\mathrm{b}}$ \\
\hline \multirow{16}{*}{ Jejunum } & \multirow{4}{*}{ CD4 } & $\mathrm{C}$ & $27.1 \pm 1.6^{b}$ & $32.1 \pm 1.1^{\mathrm{b}}$ & $31.9 \pm 1.1^{\mathrm{b}}$ \\
\hline & & E1 & $21.2 \pm 1.1^{\mathrm{a}}$ & $11.9 \pm 0.9^{\mathrm{a}}$ & $10.9 \pm 1.3^{\mathrm{a}}$ \\
\hline & & E2 & $24.3 \pm 1.3^{\mathrm{b}}$ & $21.1 \pm 1.9^{\mathrm{ab}}$ & $21.1 \pm 1.1^{\mathrm{ab}}$ \\
\hline & & E3 & $27.9 \pm 1.6^{\mathrm{b}}$ & $30.1 \pm 1.4^{\mathrm{b}}$ & $32.1 \pm 1.3^{\mathrm{b}}$ \\
\hline & \multirow{4}{*}{ TCR1 } & $\mathrm{C}$ & $12.3 \pm 1.1^{b}$ & $10.1 \pm 1.2^{\mathrm{a}}$ & $9.5 \pm 1.1^{\mathrm{a}}$ \\
\hline & & E1 & $9.4 \pm 1.2^{\mathrm{a}}$ & $9.1 \pm 1.2^{\mathrm{a}}$ & $7.8 \pm 1.1^{\mathrm{a}}$ \\
\hline & & E2 & $10.1 \pm 1.1^{\mathrm{a}}$ & $9.7 \pm 1.9^{\mathrm{a}}$ & $8.1 \pm 1.1^{\mathrm{a}}$ \\
\hline & & E3 & $12.1 \pm 1.4^{\mathrm{b}}$ & $10.8 \pm 1.4^{\mathrm{a}}$ & $10.2 \pm 1.2^{\mathrm{a}}$ \\
\hline & \multirow{4}{*}{ TCR2 } & $\mathrm{C}$ & $34.2 \pm 1.1^{b}$ & $22.0 \pm 1.8^{\mathrm{a}}$ & $7.6 \pm 1.2^{b}$ \\
\hline & & E1 & $28.4 \pm 1.2^{\mathrm{a}}$ & $23.8 \pm 1.1^{\mathrm{a}}$ & $5.1 \pm 1.4^{\mathrm{a}}$ \\
\hline & & $\mathrm{E} 2$ & $31.2 \pm 1.1^{\mathrm{a}}$ & $23.1 \pm 1.3^{\mathrm{a}}$ & $6.2 \pm 1.3^{b}$ \\
\hline & & E3 & $35.8 \pm 1.3^{\mathrm{b}}$ & $21.3 \pm 1.1^{\mathrm{a}}$ & $7.4 \pm 1.3^{\mathrm{b}}$ \\
\hline & \multirow{4}{*}{ CD8 } & $\mathrm{C}$ & $30.6 \pm 1.2^{\mathrm{a}}$ & $42.6 \pm 4.4^{\mathrm{a}}$ & $42.8 \pm 2.2^{\mathrm{a}}$ \\
\hline & & E1 & $28.1 \pm 2.1^{\mathrm{a}}$ & $91.7 \pm 7.8^{\mathrm{b}}$ & $81.3 \pm 6.8^{\mathrm{b}}$ \\
\hline & & $\mathrm{E} 2$ & $30.1 \pm 1.8^{\mathrm{a}}$ & $62.4 \pm 6.4^{\mathrm{ab}}$ & $56.8 \pm 5.1^{\mathrm{b}}$ \\
\hline & & E3 & $31.5 \pm 1.7^{\mathrm{a}}$ & $41.3 \pm 4.1^{\mathrm{a}}$ & $41.8 \pm 2.9^{\mathrm{a}}$ \\
\hline \multirow{16}{*}{ Ileocaecal junction } & \multirow{4}{*}{ CD4 } & $\mathrm{C}$ & $31.4 \pm 1.2^{\mathrm{a}}$ & $33.8 \pm 2.2^{\mathrm{a}}$ & $21.4 \pm 1.1^{b}$ \\
\hline & & E1 & $28.9 \pm 1.7^{\mathrm{a}}$ & $31.1 \pm 2.3^{\mathrm{a}}$ & $13.2 \pm 1.2^{\mathrm{a}}$ \\
\hline & & E2 & $30.5 \pm 1.3^{\mathrm{a}}$ & $33.1 \pm 2.8^{\mathrm{a}}$ & $15.3 \pm 1.1^{\mathrm{ab}}$ \\
\hline & & E3 & $32.7 \pm 1.2^{\mathrm{a}}$ & $34.6 \pm 0.2^{\mathrm{a}}$ & $22.1 \pm 1.3^{\mathrm{b}}$ \\
\hline & \multirow{4}{*}{ TCR1 } & $\mathrm{C}$ & $12.6 \pm 1.8^{\mathrm{b}}$ & $30.1 \pm 2.1^{b}$ & $10.2 \pm 1.2^{\mathrm{a}}$ \\
\hline & & E1 & $3.6 \pm 1.1^{\mathrm{a}}$ & $21.2 \pm 1.6^{\mathrm{a}}$ & $11.3 \pm 1.3^{\mathrm{a}}$ \\
\hline & & E2 & $5.1 \pm 1.1^{\mathrm{ab}}$ & $25.1 \pm 1.5^{\mathrm{a}}$ & $11.1 \pm 1.1^{\mathrm{a}}$ \\
\hline & & E3 & $12.8 \pm 1.4^{\mathrm{b}}$ & $31.2 \pm 1.7^{\mathrm{b}}$ & $10.8 \pm 1.2^{\mathrm{a}}$ \\
\hline & \multirow{4}{*}{ TCR2 } & $\mathrm{C}$ & $30.4 \pm 1.1^{\mathrm{a}}$ & $29.4 \pm 2.2^{b}$ & $7.6 \pm 1.2^{\mathrm{a}}$ \\
\hline & & E1 & $30.8 \pm 1.2^{\mathrm{a}}$ & $8.1 \pm 2.4^{\mathrm{a}}$ & $6.4 \pm 1.6^{\mathrm{a}}$ \\
\hline & & E2 & $30.2 \pm 1.1^{\mathrm{a}}$ & $16.1 \pm 2.2^{\mathrm{ab}}$ & $7.1 \pm 1.6^{\mathrm{a}}$ \\
\hline & & E3 & $31.1 \pm 1.2^{\mathrm{a}}$ & $28.9 \pm 1.8^{\mathrm{b}}$ & $8.1 \pm 1.4^{\mathrm{a}}$ \\
\hline & \multirow{4}{*}{ CD8 } & $\mathrm{C}$ & $27.8 \pm 1.4^{b}$ & $33.2 \pm 3.4^{b}$ & $34.1 \pm 3.5^{b}$ \\
\hline & & E1 & $21.1 \pm 1.8^{\mathrm{a}}$ & $11.2 \pm 3.8^{\mathrm{a}}$ & $10.3 \pm 1.8^{\mathrm{a}}$ \\
\hline & & E2 & $23.8 \pm 2.2^{\mathrm{ab}}$ & $21.2 \pm 2.9^{\mathrm{ab}}$ & $21.2 \pm 1.6^{\mathrm{ab}}$ \\
\hline & & E3 & $28.9 \pm 1.7^{b}$ & $32.8 \pm 2.6^{\mathrm{b}}$ & $33.9 \pm 2.1^{\mathrm{b}}$ \\
\hline
\end{tabular}

${ }^{\mathrm{a}, \mathrm{b}}$ significant difference between treatments at three different measurement times; means not sharing a superscript letter are significantly different 
Immunotoxic effects were noticed in chickens of all the three experimental groups administered increasing doses of OTA. The reduction of the number of intraepithelial lymphocytes seen in the lamina propria in this study was the consequence of the cytotoxic effect. The general reduction in the T-lymphocyte population of the intestinal epithelium indicated decreased local immunity and increased susceptibility to intestinal diseases.

According to the study of Lillehoj and Chung (1992), the CD8+ lymphocyte counts increase with age. In the present experiment, chickens were exposed to OTA in a period of immaturity of the digestive mucosa-associated lymphoid tissue. OTA initially produces changes in the enterocytes, which promote the penetration of antigens. Depending on their nature different classes of lymphocytes are attracted. The influx of CD8+ lymphocytes into the jejunum as a result of the presence of bacteria in the intestinal lumen was reported by Songserm et al. (2002). A sharp increase in intraepithelial CD8+ lymphocytes in the jejunum was detected after infection with E. acervulina (Lillehoj and Bacon, 1991; Lillehoj and Trout, 1996).

In conclusion, the exposure of chickens to OTA for a period of 28 days decreased the weight of chickens and the counts of leukocytes, lymphocytes and thrombocytes, altered the mucosal architecture of the duodenum, jejunum and ileocaecal junction, caused a general decrease in the intestinal TCR1, TCR2, $\mathrm{CD} 4+, \mathrm{CD} 8+$ lymphocyte populations and induced enterocyte apoptosis. The cytotoxic effect was also indicated by the replacement of the normal epithelium with a poorly functional stratified epithelium. The architecture of the intestinal mucosa was modified, resulting in a decrease of the intestinal villus height to crypt depth ratio. The changes induced in chicken weights, leukocyte counts in the peripheral blood circulation and lymphocyte populations in the intestinal mucosa may enhance the susceptibility of chickens to various infectious diseases.

\section{References}

Abdel-Wahhab, M. A., Abdel-Galil, M. M. and El-Lithey, M. (2005): Melatonin counteracts oxidative stress in rats fed an ochratoxin A contaminated diet. J. Pineal Res. 38, 130-135.

Aleo, M. D., Wyatt, R. D. and Schnellmann, R. G. (1991): Mitochondrial dysfunction is an early event in ochratoxin A but not oosporein toxicity to rat renal proximal tubules. Toxicol. Appl. Pharmacol. 107, 73-80.

Awad, W., Ghareeb, K., Böhm, J. and Zentek, J. (2013): The toxicological impacts of the Fusarium mycotoxin, deoxynivalenol, in poultry flocks with special reference to immunotoxicity. Toxins 5, 912-925.

Battacone, G., Nudda, A. and Pulina, G. (2010): Effects of ochratoxin A on livestock production. Toxins 2, 1796-1824.

Clark, H. A. and Snedeker, S. M. (2006): Ochratoxin A: its cancer risk and potential for exposure. J. Toxicol. Environ. Health 9, 265-296.

Doi, K. and Uetsuka, K. (2011): Mechanisms of mycotoxin-induced neurotoxicity through oxidative stress-associated pathways. Int. J. Mol. Sci. 12, 5213-5237. 
Elaroussi, M. A., Mohamed, F. R., El-Barkouky, E. M., Atta, A. M., Abdou, A. M. and Hatab, M. H. (2006): Experimental ochratoxicosis in broiler chickens. Avian Pathol. 35, 263-269.

Elissalde, M., Ziprin, R., Huff, W., Kubena, L. and Harvey, R. (1994): Effect of ochratoxin A on Salmonella-challenged broiler chicks. Poult. Sci. 73, 1241-1248.

Fairchild, A., Grimes, J., Porter, J., Croom, W. J. Jr., Daniel, L. and Hagler, W. M. Jr. (2005): Effects of diacetoxyscirpenol and fusaric acid on poults: Individual and combined effects of dietary diacetoxyscirpenol and fusaric acid on turkey poult performance. Int. J. Poult. Sci 4, 350-355.

Fernandez, A., Verde, M. T., Gascon, M., Ramos, L. J. and Gomez, J. (1994): Aflatoxin and its metabolites in tissues from laying hens and broiler chickens fed a contaminated diet. J. Sci. Food Agr. 65, 407-414.

Fukata, T., Sasai, K., Baba, E. and Arakawa, A. (1995): Effect of ochratoxin A on Salmonella typhimurium-challenged layer chickens. Avian Dis. 40, 924-926.

Grenier, B. and Applegate, T. J. (2013): Modulation of intestinal functions following mycotoxin ingestion: meta-analysis of published experiments in animals. Toxins 5, 396-430.

Gupta, S., Jindal, N., Khokhar, R., Gupta, A., Ledoux, D. and Rottinghaus, G. (2005): Effect of ochratoxin A on broiler chicks challenged with Salmonella gallinarum. Br. Poult. Sci. 46, 443-450.

Gupta, S., Jindal, N., Khokhar, R. S., Asrani, R. K., Ledoux, D. R. and Rottinghaus, G. E. (2008): Individual and combined effects of ochratoxin A and Salmonella enterica serovar Gallinarum infection on pathological changes in broiler chickens. Avian Pathol. 37, 265-272.

Hörnquist, E., Grdic, D., Mak, T. and Lycke, N. (1996): CD8-deficient mice exhibit augmented mucosal immune responses and intact adjuvant effects to cholera toxin. Immunology 87, 220-229.

Hudacko, R., Zhou, X. K. and Yantiss, R. K. (2013): Immunohistochemical stains for CD3 and CD8 do not improve detection of gluten-sensitive enteropathy in duodenal biopsies. Mod. Pathol. 26, 1241-1245.

International Agency for Research on Cancer (1993): Group 2B: Possibly carcinogenic to humans. In: Monographs on the Evaluation of Carcinogenic Risks of Chemicals to Humans. Int. Agency Cancer Res., Lyon, France. pp. 245-395.

Janaczyk, B., Pliszczak-Król, A., Graczyk, S., Houszka, M. and Rouibah, K. (2006): Morphological and functional evaluation of chicken blood leukocytes in chronic ochratoxicosis. Int. J. Poult. Sci. 5, 191-194.

Koynarski, V., Stoev, S., Grozeva, N., Mirtcheva, T., Daskalov, H., Mitev, J. and Mantle, P. (2007): Experimental coccidiosis provoked by Eimeria acervulina in chicks simultaneously fed on ochratoxin A contaminated diet. Res. Vet. Sci. 82, 225-231.

Kumar, A., Jindal, N., Shukla, C. L., Asrani, R. K., Ledoux, D. R. and Rottinghaus, G. E. (2004): Pathological changes in broiler chickens fed ochratoxin A and inoculated with Escherichia coli. Avian Pathol. 33, 413-417.

Kumar, A., Jindal, N., Shukla, C., Pal, Y., Ledoux, D. and Rottinghaus, G. (2003): Effect of ochratoxin A on Escherichia coli-challenged broiler chicks. Avian Dis. 47, 415-424.

Kumar, R. and Balachandran, C. (2009): Histopathological changes in broiler chickens fed aflatoxin and cyclopiazonic acid. Vet. Arhiv 79, 31-40.

Kunisawa, J., Takahashi, I. and Kiyono, H. (2007): Intraepithelial lymphocytes: their shared and divergent immunological behaviors in the small and large intestine. Immunol. Rev. 215, 136-153.

Lillehoj, H. S. and Bacon, L. D. (1991): Intestinal intraepithelial lymphocytes expressing CD8 antigen are increased following challenge infection with Eimeria acervulina. Avian Dis. 35, 294-301.

Lillehoj, H. and Chung, K. (1992): Postnatal development of T-lymphocyte subpopulations in the intestinal intraepithelium and lamina propria in chickens. Vet. Immunol. Immunopathol. 31, 347-360.

Lillehoj, H. S. and Trout, J. M. (1996): Avian gut-associated lymphoid tissues and intestinal immune responses to Eimeria parasites. Clin. Microbiol. Rev. 9, 349-360.

Liu, J., Wang, Y., Cui, J., Xing, L., Shen, H., Wu, S., Lian, H., Wang, J. and Yan, X. (2012): Ochratoxin A induces oxidative DNA damage and G1 phase arrest in human peripheral blood mononuclear cells in vitro. Toxicol. Lett. 211, 164-171. 
Maresca, M. and Fantini, J. (2010): Some food-associated mycotoxins as potential risk factors in humans predisposed to chronic intestinal inflammatory diseases. Toxicon 56, 282-294.

O'Brien, E. and Dietrich, D. (2005): Ochratoxin A: the continuing enigma. Crit. Rev. Toxicol. 35, 33-60.

Omar, R. F., Hasinoff, B. B., Mejilla, F. and Rahimtula, A. D. (1990): Mechanism of ochratoxin A stimulated lipid peroxidation. Biochem. Pharmacol. 40, 1183-1191.

Oswald, I. P., Desautels, C., Laffitte, J., Fournout, S., Peres, S. Y., Odin, M., Bars, P. L., Bars, J. L. and Fairbrother, J. M. (2003): Mycotoxin fumonisin B1 increases intestinal colonization by pathogenic Escherichia coli in pigs. Appl. Environ. Microbiol. 69, 5870-5874.

Ranaldi, G., Caprini, V., Sambuy, Y., Perozzi, G. and Murgia, C. (2009): Intracellular zinc stores protect the intestinal epithelium from ochratoxin A toxicity. Toxicol. In Vitro 23, 1516-1521.

Revajová, V., Levkut, M., Levkutová, M., Bořutová, R., Grešaková, L., Košiková, B. and Leng, L. (2013): Effect of lignin supplementation of a diet contaminated with Fusarium mycotoxins on blood and intestinal lymphocyte subpopulations in chickens. Acta Vet. Hung. 61, 1-12.

Sauvant, C., Holzinger, H. and Gekle, M. (2005): The nephrotoxin ochratoxin A induces key parameters of chronic interstitial nephropathy in renal proximal tubular cells. Cell. Physiol. Biochem. 15, 125-134.

Schrickx, J., Lektarau, Y. and Fink-Gremmels, J. (2006): Ochratoxin A secretion by ATPdependent membrane transporters in Caco-2 cells. Arch. Toxicol. 80, 243-249.

Shi, C. S., Leonardi, A., Kyriakis, J., Siebenlist, U. and Kehrl, J. H. (1999): TNF-mediated activation of the stress-activated protein kinase pathway: TNF receptor-associated factor 2 recruits and activates germinal center kinase related. J. Immunol. 163, 3279-3285.

Shlig, A. (2009): Effect of vitamin E and selenium supplement in reducing aflatoxicosis on performance and blood parameters in broiler chicks. Iraqi J. Vet. Sci. 23, 97-103.

Sklan, D., Shelly, M., Makovsky, B., Geyra, A., Klipper, E. and Friedman, A. (2003): The effect of chronic feeding of diacetoxyscirpenol and T-2 toxin on performance, health, small intestinal physiology and antibody production in turkey poults. Br. Poult. Sci. 44, 46-52.

Solcan, C., Timofte, D., Floristean, V. C., Carter, S. D. and Solcan, G. (2013): Ultrastructural lesions and immunohistochemical analysis of Bcl-2 protein expression in the kidney of chickens with experimental ochratoxicosis. Acta Vet. Hung. 61, 344-353.

Songserm, T., Zekarias, B., van Roozelaar, D. J., Kok, R. S., Pol, J. M., Pijpers, A. A. and ter Huurne, A. A. (2002): Experimental reproduction of malabsorption syndrome with different combinations of reovirus, Escherichia coli, and treated homogenates obtained from broilers. Avian Dis. 46, 87-94.

Stoev, S. D., Dutton, M. F., Njobeh, P. B., Mosonik, J. S. and Steenkamp, P. A. (2010): Mycotoxic nephropathy in Bulgarian pigs and chickens: complex aetiology and similarity to Balkan endemic nephropathy. Food Addit. Contam. A 27, 72-88.

Stoev, S. D., Koynarsky, V. and Mantle, P. (2002): Clinicomorphological studies in chicks fed ochratoxin A while simultaneously developing coccidiosis. Vet. Res. Commun. 26, 189-204.

Szabó, A., Szabó-Fodor, J., Fébel, H., Romvári, R. and Kovács, M. (2014): Individual and combined haematotoxic effects of fumonisin B1 and T-2 mycotoxins in rabbits. Food Chem. Toxicol. 72, 257-264.

Talebi, A., Asri-Rezaei, S., Rozeh-Chai, R. and Sahraei, R. (2005): Comparative studies on haematological values of broiler strains (Ross, Cobb, Arbor Acres and Arian). Int. J. Poult. Sci. 4, 573-579.

Vandenbroucke, V., Croubels, S., Martel, A., Verbrugghe, E., Goossens, J., Van Deun, K., Boyen, F., Thompson, A., Shearer, N. and De Backer, P. (2011): The mycotoxin deoxynivalenol potentiates intestinal inflammation by Salmonella Typhimurium in porcine ileal loops. PLoS ONE 6, e23871.

Wakenell, P. (2010): Hematology of chickens and turkeys. In: Douglas, J. W. and Wardrop, J. K. (eds) Schalm's Veterinary Hematology. Sixth edition. Blackwell Publishing Ltd., Ames, Iowa, USA. pp. 958-967.

Yo-Ping, L., Chung-Jiuan, J. and Shu-Ching, C. (2011): The roles of CD4 ${ }^{+}$T cells in tumor immunity. ISRN Immunol., Article ID 497397. 